RESEARCH ARTICLE

\title{
Assessment of Ground Water Quality for Irrigation in the Farms of Horticultural College and Research Institute, Periyakulam, Theni District
}

\author{
Sellamuthu $\mathbf{K} \mathbf{M}^{\mathbf{1}}$, Malathi $\mathbf{P}^{\mathbf{1}}$ and Kumaraperumal $\mathbf{R}^{\mathbf{2}}$ \\ $1 *$ Department of Natural Resource Management, Horticultural College and Research Institute, Periyakulam-625604 \\ ${ }^{2}$ Department of Remote Sensing and GIS, Tamil Nadu Agricultural University, Coimbatore-641003
}

\begin{abstract}
Ground water quality of Horticultural College and Research Institute (HC \& RI), Periyakulam located in Theni District, Tamil Nadu was assessed during January 2021. Ground water samples were collected from bore wells and their quality parameters were assessed. $\mathrm{pH}$ values ranged from 6.88 to 7.81 ; electrical conductivity values ranged from 0.20 to $1.28 \mathrm{dSm}^{-1}$ and most of the samples were under high salinity class (C3) (84.6\%). Calcium, magnesium, sodium and potassium content ranged from 1.68 to $4.72 \mathrm{~m} . \mathrm{e} \mathrm{L}^{-1}, 0.72$ to 10.6 m.e $\mathrm{L}^{-1}, 1.35$ to $10.3 \mathrm{~m} . \mathrm{L}^{-1}$ and 0.05 to 0.23 m.e $\mathrm{L}^{-1}$ respectively. Most of the samples were found to be magnesium dominating and magnesium exceeds the calcium content in most of the water samples. Magnesium toxicity will be exhibited in the continuous use of water to crops. No carbonates were noticed. Bicarbonates, chloride and sulphate concentration varied from 2.0 to 13.4 m.e $\mathrm{L}^{-1}, 1.12$ to $7.52 \mathrm{~m} . \mathrm{e} \mathrm{L}^{-1}$ and 0.02 to 0.99 m.e $\mathrm{L}^{-1}$ respectively. The sequence of cations were found in the order of $\mathrm{Mg}^{2+}>\mathrm{Na}^{+}>\mathrm{Ca}^{2+}>\mathrm{K}^{+}$ and anions followed the sequence of $\mathrm{HCO}^{3-}>\mathrm{Cl}^{-}>\mathrm{SO}_{4}{ }^{2-}$. Total hardness in the study area varied from 120 to $686 \mathrm{mg} \mathrm{L}^{-1}$ and majority of the samples (61.5 $\%$ ) were very hard. RSC values varied from -3.76 to $5.24 \mathrm{meL}^{-1}$ and most of the samples come under the moderate category (61.5\%) followed by safe (38.5\%). RSBC varied from 0.32 to 9.48 m.e $\mathrm{L}^{-1}$ and majority of the samples come under the safe category $(61.5 \%)$ followed by unsafe $(23.1 \%)$ and moderate (15.4\%). SAR values ranged from 0.83 to 5.11 and all the samples were found to be low sodium category (S1). There is no sodicity problem existing in the ground waters. In the present study, the permeability index ranged from 39.4 to 80.3 per cent and the majority of the samples come under the permeability hazard class II, which can be used for irrigation without any permeability problem in the soils. As per CSSRI, Karnal classification, majority of the ground water samples coming under good (76.9), followed by marginally alkaline (15.4\%) and alkaline (7.7\%). Marginally alkaline and alkaline waters should be managed carefully to avoid a negative impacts on soil and crops.
\end{abstract}

Keywords: Ground water quality; Horticultural College and Research Institute; Periyakulam; Tamil Nadu.

\section{INTRODUCTION}

Geochemical studies of groundwater provide a better understanding of possible temporal changes in the quality of ground water. The suitability of groundwater for irrigation purposes is determined by its geochemistry. Ground water quality is being on a high note for the survival of human beings as well as all other living beings on the earth. Water quality is the most important for field crops, crops grown in small amounts of growth media or hydroponically. Greenhouse cultivation and high tunnel growth environments also increase the importance of water quality because irrigation is the only source of water. Water used for irrigation may vary significantly in quality aspects depending upon the type and quantity of dissolved salts. Salts present in irrigation water may be small but they will add a significant amount of salt load to the irrigated fields. The suitability of water for irrigation is determined not only by the total amount of salts present but also by the kind of salts present in the irrigation water (Sellamuthu et al., 2011) 
Quality of water is found to assume greater importance with the rising pressure on industries and agriculture and the rise in the standard of living. According to FAO statistics, $20 \%$ of the land is irrigated but produces $40 \%$ of the crops (Tiri et al., 2018). Irrigation is an effective way to improve productivity significantly; however, there are environmental risks associated with irrigation, especially water stagnation and increased salinity. The quality of groundwater results from all the processes and reactions that act on the water that is condensed in the atmosphere until the time it is discharged by a well or spring (Kesavan and Parameswari, 2005). The availability of fresh water is vital for drinking, cultivation and ensures the sustainable increase of crop yield (Jeyaraj et al., 2019). In this study, an attempt was made to assess the ground water quality of farms of Horticultural College and Research Institute, Periyakulam and their suitability for irrigation.

\section{MATERIAL AND METHODS}

Horticultural College and Research Institute, Periyakulm, is located in Theni District, Tamil Nadu, on the foothill of Kodaikanal. It contains three Farms viz., Eastern Farm, Central Farm and Western Farm and altogether, thirteen bore wells were used for irrigating the farms. Water samples from 13 bore wells were collected and analyzed for various chemical parameters. The water samples were analyzed for quality parameters as per the standard procedure given by Richards (1969). Classification of quality of irrigation water was done as per standard procedures. Residual Sodium Carbonate (RSC) was classified as per Eaton (1950) and Wilcox et al. (1954). Salinity and sodicity classes were classified as per Richards (1969). Residual Sodium Bicarbonate (RSBC) was calculated and classified based on Gupta and Gupta (1987). The results were also interpreted as per Ayers and Westcot (1994) where the quality of irrigation water was interpreted based on the degree of salinity and SAR to judge infiltration problems on soils and toxicity of ions.

\section{EC and Sodium Adsorption Ratio (SAR)}

EC and SAR were classified based on salinity and sodicity classes as per Richards (1969). SAR is calculated as follows.

$$
S A R=\frac{N a^{+}}{\sqrt{\frac{C a^{2+}+M g^{2+}}{2}}}
$$

Where $\mathrm{Na}^{+}, \mathrm{Ca}^{2+}, \mathrm{Mg}^{2+}$ are concentrations of respective ions in m.e $\mathrm{L}^{-1}$

\section{Soluble sodium percent (SSP)}

Soluble sodium percent

$$
=\frac{\mathrm{Na}^{+}+\mathrm{K}^{+}}{\mathrm{Ca}^{2+}+\mathrm{Mg}^{2+}+\mathrm{Na}^{+}+\mathrm{K}^{+}} \times 100
$$

Where $\mathrm{Ca}^{2+}, \mathrm{Mg}^{2+}, \mathrm{Na}^{+}$andK $\mathrm{K}^{+}$are concentrations of respective ions in m.e $\mathrm{L}^{-1}$

SSP was classified as per Wilcox (1955) with Excellent (<20), Good (20-40), Permissible (40-60), Doubtful (60-80) and Unsuitable (>80) classes.

\section{Magnesium hazard}

Magnesium hazard was calculated as per Raghunath (1987). If the value is $<50.0$, classified under non-hazardous and the value exceeds 50.0 will cause a magnesium hazard.

$$
\text { Magnesium Hazard }=\frac{\mathrm{Mg}^{2+}}{\left(\mathrm{Ca}^{2+}+\mathrm{Mg}^{2+}\right)} \times 100
$$

Where $\mathrm{Ca}^{2+}$ and $\mathrm{Mg}^{2+}$ are concentrations of respective ions in $\mathrm{m} . \mathrm{L}^{-1}$

\section{Total hardness}

Hardness is an indication of the amount of calcium and magnesium in the water and is expressed as $\mathrm{mg}$ of $\mathrm{CaCO}_{3} \mathrm{~L}^{-1}$, or parts per million $\mathrm{CaCO}_{3}$ (Table 1). The amounts of these two elements in irrigation water are variable. Water with hardness in the range of 100 to $150 \mathrm{mg} \mathrm{CaCO}_{3} \mathrm{~L}^{-1}$ is considered desirable for plant growth. Plants tolerate high levels of these elements, so toxicity is not normally a problem. However, excessive hardness may cause foliar deposits of calcium or magnesium carbonate under overhead irrigation. Soft water $(<50 \mathrm{mg} \mathrm{CaCO}$ $\mathrm{L}^{-1}$ ) may need additional calcium and or magnesium over and above that supplied by typical fertilizers to achieve good plant growth.

Table 1. Criteria for the classification of total hardness

\begin{tabular}{llll}
\hline $\begin{array}{c}\text { Criteria } \\
\left(\mathbf{m g ~ L}^{-1} \mathbf{C a C O}_{3}\right)\end{array}$ & Class & $\begin{array}{c}\text { Criteria } \\
\left(\mathbf{m g ~ L}^{-1} \mathbf{C a C O}_{3}\right)\end{array}$ & Class \\
\hline$<50$ & Soft & $151-250$ & $\begin{array}{l}\text { Moderately } \\
\text { Hard }\end{array}$ \\
$51-100$ & Moderately Soft & $251-350$ & Hard \\
$101-150$ & Slightly hard & $>350$ & Very Hard \\
\hline (EPA, 2001) & & &
\end{tabular}

\section{Residual Sodium Carbonate (RSC)}

RSC was calculated as per Eaton (1950).

$\mathrm{RSC}=\left(\mathrm{CO}_{3}{ }^{2-}+\mathrm{HCO}_{3}{ }^{-}\right)-\left(\mathrm{Ca}^{2+}+\mathrm{Mg}^{2+}\right)$

Where $\mathrm{CO}_{3}{ }^{2-}, \mathrm{HCO}_{3}, \mathrm{Ca}^{2+}, \mathrm{Mg}^{2+}$ are concentrations of respective ions in $\mathrm{m} . \mathrm{L} \mathrm{L}^{-1}$. 
Wilcox et. al, (1954) classified the water based on RSC values as Satisfactory $\left(<1.25\right.$ m.e $\left.\mathrm{L}^{-1}\right)$, Marginal (1.25 - 2.50 m.e L $\left.{ }^{-1}\right)$ and Unsatisfactory (> 2.50 m.e $\left.\mathrm{L}^{-1}\right)$.

\section{Residual Sodium Bicarbonate (RSBC)}

RSBC was calculated as $\mathrm{HCO}_{3}-\mathrm{Ca}$ and classified as satisfactory ( $<5$ m.e $\mathrm{L}^{-1}$ ), marginal (5-10 m.e $\left.\mathrm{L}^{-1}\right)$ and unsatisfactory (> 10 m.e $\left.\mathrm{L}^{-1}\right)$ as per Gupta (1983). When rainfall is appreciable, the effective salt balance is zero. High values of EC and SAR would reduce the suggested permissible limits. Higher water table and poor drainage may also reduce the permissible limits.

\section{Permeability index}

Permeability index or Doneen's Permeability Index was calculated as per Doneen (1966) as follows.

Permeability Index

$$
=\frac{\mathrm{Na}^{+}+\left(\mathrm{HCO}_{3}^{-}\right)^{1 / 2}}{\mathrm{Ca}^{2+}+\mathrm{Mg}^{2+}+\mathrm{Na}^{+}} \times 100
$$

Where $\mathrm{HCO}_{3}{ }_{3}, \mathrm{Ca}^{2+}, \mathrm{Mg}^{2+}, \mathrm{Na}^{+}$are concentrations of respective ions in m.e $\mathrm{L}^{-1}$.

The index varies with soils having different initial permeability.

\section{Suitability assessment of ground waters for irrigation}

Based on EC, SAR and RSC, water samples were classified into different categories as per the classification of All India Coordinated Research Project (AICRP) on Management of Salt affected Soils and Use of Saline Water in Agriculture as given by Gupta et al. (1994) (Table 2.)

Table 2. Suitability assessment of ground waters for irrigation

\begin{tabular}{lcccc}
\hline \multicolumn{1}{c}{ Water quality } & $\begin{array}{c}\text { Sub } \\
\text { class }\end{array}$ & $\begin{array}{c}\text { EC } \\
\left(\mathbf{d S m}^{-1}\right)\end{array}$ & $\begin{array}{c}\text { SAR } \\
\left(\mathbf{m m o l ~ L}^{-\mathbf{1}}\right)^{\mathbf{1 / 2}}\end{array}$ & $\begin{array}{c}\text { RSC } \\
\left(\mathbf{m} . \mathbf{e} \mathbf{~ L}^{-1}\right)\end{array}$ \\
\hline A. Good & A & $<2$ & $<10$ & $<2.5$ \\
B. Saline & & & & \\
I. Marginally saline & B1 & $2-4$ & $<10$ & $<2.5$ \\
ii. Saline & B2 & $>4$ & $<10$ & $<2.5$ \\
iii. High SAR saline & B3 & $>4$ & $>10$ & $<2.5$ \\
C. Alkali water & & & & \\
i. Marginally alkaline & C1 & $<4$ & $<10$ & $2.5-4.0$ \\
ii. Alkaline & C2 & $<4$ & $<10$ & $>4.0$ \\
iii. High alkaline & C3 & Variable & $>10$ & $>4.0$ \\
\hline
\end{tabular}

\section{RESULTS AND DISCUSSION}

pH

$\mathrm{pH}$ is the most important parameter for determining the reaction of groundwater. Natural waters will be having $\mathrm{pH}$ values from 6.0 to 8.5 . $\mathrm{pH}$ values of water samples ranged from 6.88 to 7.81 (Table 9). $\mathrm{pH}$ of the ground water samples varied between neutral to mildly alkaline in reaction.

\section{Salinity (EC)}

Electrical conductivity values ranged from 0.20 to $1.28 \mathrm{dSm}^{-1}$ (Table 9). The samples were classified under the USSL classification (Richards,1969). Most of the samples come under high salinity class $\left(\mathrm{C}_{3}\right)$ $(84.6 \%)$ followed by Medium Salinity Class $\left(C_{2}\right)(7.7$ $\%)$ andlow salinity class $\left(\mathrm{C}_{1}\right)(7.7 \%)$ (Figure 1$)$.

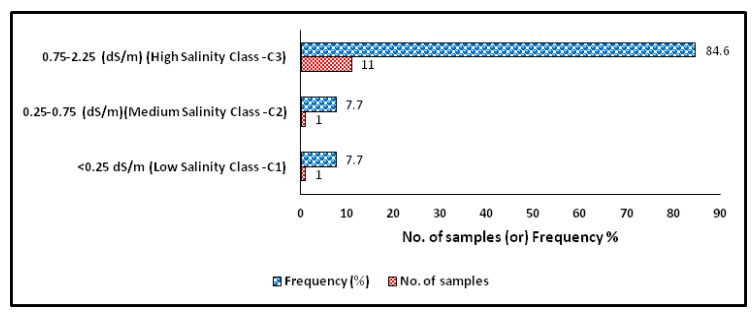

Figure. 1. Classification of irrigation water quality based on EC values

\section{Cations}

The water samples were analyzed for cations like calcium, magnesium, sodium and potassium (Table 9). Calcium content ranged from 1.68 to 4.72 m.e $\mathrm{L}^{-1}$. Magnesium content varied from 0.72 to $10.6 \mathrm{~m}$.e $\mathrm{L}^{-1}$. Sodium content was observed between 1.35 to 10.3 m.e $\mathrm{L}^{-1}$. Potassium content varied from 0.05 to 0.23 m.e $\mathrm{L}^{-1}$. Most of the water samples were found to be magnesium dominating. Magnesium hazard was observed in 92.3 per cent of samples (Table 3). Magnesium toxicity may be exhibited with continuous use of this water to crops. Similar findings were also reported by Sellamuthu et al. (2012) in the PAP basin, Tamil Nadu.

Table 3. Classification of irrigation water quality based on magnesium hazard

\begin{tabular}{ccc}
\hline Magnesium Hazard & No. of samples & Frequency(\%) \\
\hline$<50 \%$ & 1 & 7.7 \\
$>50 \%$ & 12 & 92.3 \\
\hline
\end{tabular}

\section{Anions}

Anions like carbonate, bicarbonate, chloride and sulphate were analyzed in the water samples (Table 9). Carbonates were absent in the water samples. Bicarbonates were found to dominate and they ranged from 2.0 to $13.4 \mathrm{~m} . \mathrm{e} \mathrm{L}^{-1}$. Chloride concentration varied from 1.12 to 7.52 m.e L $\mathrm{L}^{-1}$. Sulphate concentration varied from 0.02 to 0.99 
m.e $\mathrm{L}^{-1}$. Chloride concentration in water samples classified as excellent $\left(<5\right.$ m.e $\left.\mathrm{L}^{-1}\right)$, good $(5-10$ m.e $\mathrm{L}^{-1}$ ) and injurious (>10 m.e $\left.\mathrm{L}^{-1}\right)$. Most of the water samples (53.8\%) coming under the excellent category, followed by thegood category (46.2\%) (Figure 2).

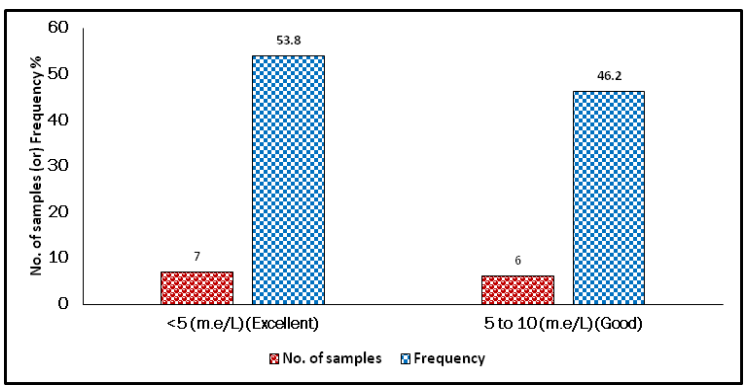

Figure 2. Classification of irrigation water quality based on chloride content

\section{Total hardness}

Total hardness was worked out and it varied from 120 to $686 \mathrm{mg} \mathrm{L}^{-1}$ (Table 10). Hardness indicated that 61.5 per cent of samples were very hard, followed by hard $(23.1 \%)$, moderately hard $(7.7 \%)$ and slightly hard (7.7\%) (Figure 3 ).

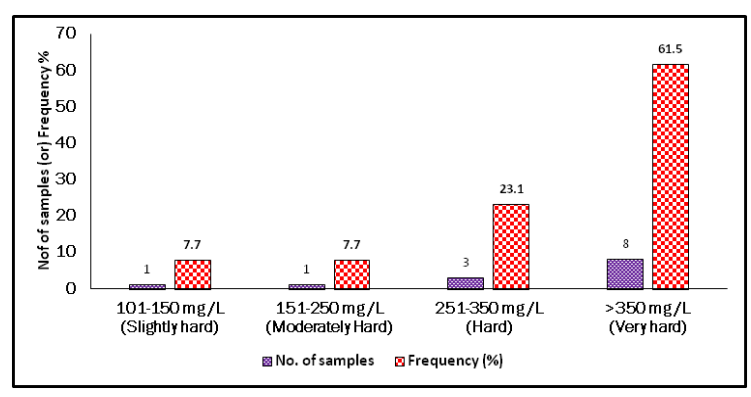

Figure 3. Classification of irrigation water quality based on the total hardness

\section{Residual sodium carbonate (RSC) and Residual sodium bicarbonate (RSBC)}

RSC values varied from -3.76 to 5.24 m.e $\mathrm{L}^{-1}$ (Table 10). RSC values were classified as safe $(<1.25)$, moderate (1.25-2.50) and unsafe (>2.50). Most of the samples are coming under the moderate category $(61.5 \%)$ followed by safe (38.5\%). RSBC varied from 0.32 to 9.48 m.e $\mathrm{L}^{-1}$. Residual sodium bicarbonates also come under satisfactory (61.5\%) followed byunsatisfactory (23.1\%) and marginal (15.4\%) (Table 4).

Table 4. Classification of irrigation water quality based on RSC and RSBC

\begin{tabular}{lccccc}
\hline \multicolumn{1}{c}{ RSC (m.e L-1) } & No. of Samples & Frequency (\%) & RSBC (m.e L-1) & No. of Samples & Frequency (\%) \\
\hline$<1.25$ (Safe) & 5 & 38.5 & $<5$ (Satisfactory) & 8 & 61.5 \\
$1.25-2.5$ & 8 & 61.5 & $5-10$ (Marginal) & 2 & 15.4 \\
(Moderate) & 0 & 0.0 & $>10$ (Unsatisfactory) & 3 & 23.1 \\
$>2.5$ (Unsafe) & & &
\end{tabular}

\section{Sodium Adsorption Ratio (SAR)}

SAR values ranged from 0.83 to 5.11 (Table 10). All the samples are coming under the low sodium category $\left(S_{1}<10\right)$ (Table 5$)$. There is no sodicity problem observed in the ground water samples.

Table 5. Classification of irrigation water quality based on SAR

\begin{tabular}{lccc}
\hline $\begin{array}{c}\text { SAR } \\
(\mathbf{m} \text { mol } \\
\left.\mathbf{L}^{-\mathbf{1}}\right)^{\mathbf{1 / 2}}\end{array}$ & Category & $\begin{array}{c}\text { No. of } \\
\text { samples }\end{array}$ & $\begin{array}{c}\text { Frequency } \\
(\mathbf{\%})\end{array}$ \\
\hline$<10$ Low Sodium Class $\left(\mathrm{S}_{1}\right)$ & 13 & 100 \\
10-18 Medium Sodium Class $\left(\mathrm{S}_{2}\right)$ & 0 & 0.0 \\
18-26 High Sodium Class $\left(\mathrm{S}_{3}\right)$ & 0 & 0.0 \\
$>26$ Very High Sodium Class $\left(\mathrm{S}_{4}\right)$ & 0 & 0.0 \\
\hline
\end{tabular}

\section{Soluble sodium percent (SSP)}

Soluble sodium per cent was worked out and it ranged from 16.2 to 59.3 per cent (Table 10). SSP levels were classified and majority of the samples come under good (46.2\%) and permissible level (46.2\%) followed by excellent $(7.7 \%)$ category (Table 6).
Table 6. Classification of irrigation water quality based on SSP

\begin{tabular}{cccc}
\hline SSP (\%) & Category & No. of samples & Frequency (\%) \\
\hline$<20$ & Excellent & 1 & 7.7 \\
$20-40$ & Good & 6 & 46.2 \\
$40-60$ & Permissible & 6 & 46.2 \\
$60-80$ & Doubtful & 0 & 0.0 \\
$>80$ & Unsuitable & 0 & 0.0 \\
\hline
\end{tabular}

\section{Permeability index}

The soil permeability is affected by the long term use of irrigation water. Sodium, calcium, magnesium and bicarbonate content of the soil influence it. Doneen evolved a criterion for assessing the suitability of water for irrigation based on the permeability index. The permeability index for the water samples is given in Table 10. Accordingly, waters can be classified as Class I, Class II and Class III orders. Class I and Class II waters are categorized as good for irrigation with a 75 per cent or more permeability index. Class III water is unsuitable with less than 25 per cent of permeability index. In the present study, permeability Index ranged from 39.4 
to 80.3 per cent. Majority of the samples (76.9\%) are coming under the permeability hazard class II (Table 7).

Table 7. Classification of irrigation water quality based on Permeability Index

\begin{tabular}{clcc}
\hline $\begin{array}{c}\text { Permeability } \\
\text { Index (\%) }\end{array}$ & Category & $\begin{array}{c}\text { No. of } \\
\text { samples }\end{array}$ & $\begin{array}{c}\text { Frequency } \\
\text { (\%) }\end{array}$ \\
\hline$>75$ & Class I (Suitable) & 3 & 23.1 \\
$25-75$ & Class II (Good) & 10 & 76.9 \\
$<25$ & Class III (Unsuitable) & 0 & 0.0 \\
\hline
\end{tabular}

\section{Suitability assessment of ground waters for irrigation}

Screening of groundwater samples for their suitability to irrigation done on the basis of EC, SAR and RSC values as suggested by Central Soil Salinity Research Institute, Karnal is given in Table 8. Majority of the samples coming under good (76.9) followed by marginally alkaline (15.4\%) and alkaline (7.7\%). Alkalinity of the ground water samples might be due to the presence of bicarbonates.

Table 8. Suitability assessment of ground waters for irrigation

\begin{tabular}{|c|c|c|c|c|c|c|}
\hline Water quality & $\begin{array}{l}\text { Sub } \\
\text { class }\end{array}$ & $E C\left(d S m^{-1}\right)$ & $\begin{array}{c}\text { SAR } \\
\left(\mathrm{m} . \mathrm{mol} \mathrm{L}^{-1}\right)^{1 / 2}\end{array}$ & $\begin{array}{c}\text { RSC } \\
\left(\mathbf{m} . \mathbf{L ~ L}^{-1}\right)\end{array}$ & No of samples & Frequency (\%) \\
\hline A. Good & $A$ & $<2$ & $<10$ & $<2.5$ & 10 & 76.9 \\
\hline \multicolumn{7}{|l|}{ B. Saline } \\
\hline I. Marginally saline & B1 & $2-4$ & $<10$ & $<2.5$ & - & - \\
\hline ii. Saline & B2 & $>4$ & $<10$ & $<2.5$ & - & - \\
\hline iii. High SAR saline & B3 & $>4$ & $>10$ & $<2.5$ & - & - \\
\hline \multicolumn{7}{|l|}{ C. Alkali water } \\
\hline i. Marginally alkaline & $\mathrm{C} 1$ & $<4$ & $<10$ & $2.5-4.0$ & 2 & 15.4 \\
\hline ii. Alkaline & $\mathrm{C} 2$ & $<4$ & $<10$ & $>4.0$ & 1 & 7.7 \\
\hline iii. High alkaline & $\mathrm{C} 3$ & Variable & $>10$ & $>4.0$ & - & - \\
\hline
\end{tabular}

\section{Hydro- geochemical facies of groundwater}

The Piper diagram is used to infer hydrogeochemical facies (Piper,1969). It is a graphical representation of the chemistry of a water sample or samples. These plots include two triangles, one for plotting cations and the other for plotting

Table 9. Ground water quality parameters of Horticultural College and Research Institute, Periyakulam

\begin{tabular}{|c|c|c|c|c|c|c|c|c|c|c|c|}
\hline $\begin{array}{l}\text { SI } \\
\text { No. }\end{array}$ & Lat $\left({ }^{\circ} \mathbf{N}\right)$ & Long ( $\left.{ }^{\circ} \mathrm{E}\right)$ & pH & $\begin{array}{c}E C \\
\left(\mathrm{dSm}^{-1}\right)\end{array}$ & $\begin{array}{c}\mathrm{HCO}_{3} \\
\left(\mathrm{~m} . \mathrm{e} \mathrm{L}^{-1}\right)\end{array}$ & $\begin{array}{c}\mathrm{Cl} \\
\left(\mathrm{m} . \mathrm{e} \mathrm{L}^{-1}\right)\end{array}$ & $\begin{array}{c}\mathrm{SO}_{4} \\
\left(\mathrm{~m} . \mathrm{L}^{-1}\right)\end{array}$ & $\begin{array}{c}\mathrm{Na} \\
\left(\mathrm{m} . \mathrm{e} \mathrm{L}^{-1}\right)\end{array}$ & $\begin{array}{c}K \\
\left(m . e L^{-1}\right)\end{array}$ & $\begin{array}{c}\mathrm{Ca} \\
\left(\mathrm{m} . \mathrm{e} \mathrm{L}^{-1}\right)\end{array}$ & $\begin{array}{c}\text { Mg } \\
\left(\mathrm{m} . \mathrm{e} \mathrm{L}^{-1}\right)\end{array}$ \\
\hline 1 & 10.121216 & 77.589005 & 7.15 & 0.93 & 10.0 & 4.16 & 0.63 & 7.61 & 0.10 & 2.80 & 5.04 \\
\hline 2 & 10.120902 & 77.588903 & 7.23 & 0.77 & 9.60 & 2.80 & 0.24 & 7.72 & 0.08 & 2.48 & 3.28 \\
\hline 3 & 10.120512 & 77.590202 & 6.99 & 1.27 & 13.4 & 5.84 & 0.26 & 10.3 & 0.10 & 3.92 & 4.24 \\
\hline 4 & 10.127685 & 77.592694 & 7.13 & 1.11 & 9.40 & 6.08 & 0.20 & 7.61 & 0.08 & 4.08 & 4.72 \\
\hline 5 & 10.123827 & 77.593692 & 6.88 & 1.28 & 10.0 & 7.52 & 0.19 & 3.74 & 0.15 & 3.12 & 10.6 \\
\hline 6 & 10.119254 & 77.588775 & 7.61 & 0.30 & 3.60 & 1.12 & 0.13 & 1.48 & 0.13 & 1.84 & 1.84 \\
\hline 7 & 10.127646 & 77.597345 & 7.36 & 1.05 & 10.6 & 5.44 & 0.02 & 8.48 & 0.23 & 3.84 & 4.16 \\
\hline 8 & 10.126205 & 77.596398 & 7.67 & 0.20 & 2.00 & 1.12 & 0.57 & 1.35 & 0.10 & 1.68 & 0.72 \\
\hline 9 & 10.120512 & 77.590202 & 7.22 & 0.99 & 7.80 & 4.64 & 0.99 & 7.83 & 0.21 & 2.72 & 2.80 \\
\hline 10 & 10.129726 & 77.597785 & 7.70 & 0.84 & 5.40 & 2.08 & 0.21 & 2.70 & 0.21 & 1.68 & 3.60 \\
\hline 11 & 10.123399 & 77.594699 & 7.19 & 1.06 & 8.20 & 6.24 & 0.05 & 3.48 & 0.13 & 3.92 & 6.64 \\
\hline 12 & 10.121319 & 77.594019 & 7.81 & 0.90 & 9.00 & 2.56 & 0.05 & 1.83 & 0.05 & 4.72 & 4.96 \\
\hline \multirow[t]{4}{*}{13} & 10.129435 & 77.588076 & 7.29 & 1.15 & 9.00 & 6.40 & 0.11 & 3.30 & 0.05 & 3.04 & 9.60 \\
\hline & & Min. & 6.88 & 0.20 & 2.00 & 1.12 & 0.02 & 1.35 & 0.05 & 1.68 & 0.72 \\
\hline & & Max. & 7.81 & 1.28 & 13.4 & 7.52 & 0.99 & 10.3 & 0.23 & 4.72 & 10.6 \\
\hline & & Mean & 7.33 & 0.91 & 8.31 & 4.31 & 0.28 & 5.19 & 0.12 & 3.06 & 4.79 \\
\hline
\end{tabular}


anions. The cations and anion fields are combined to show a single point in a diamond-shaped field, from which inference is drawn on the basis of the hydro-geochemical facies concept. It indicates that the ground water samples were dominating with magnesium and bicarbonates (Figure.4)

Table 10. Derived parameters of ground water quality of Horticultural College and Research Institute, Periyakulam

\begin{tabular}{|c|c|c|c|c|c|c|c|c|c|}
\hline SI No. & $\begin{array}{c}\text { Total } \\
\text { Hardness } \\
\left(\mathrm{mg} \mathrm{L}^{-1}\right)\end{array}$ & $\begin{array}{c}\text { RSBC } \\
\left(m . e L^{-1}\right)\end{array}$ & $\begin{array}{c}\text { RSC } \\
\left(m \cdot e L^{-1}\right)\end{array}$ & $\begin{array}{c}\text { SAR } \\
\left(\mathrm{m} . \mathrm{mol} \mathrm{L}^{-1}\right)^{1 / 2}\end{array}$ & $\begin{array}{l}\text { SSP } \\
(\%)\end{array}$ & $\begin{array}{l}\text { Permeability } \\
\text { Index (\%) }\end{array}$ & $\begin{array}{c}\text { Mg } \\
\text { Hazard }\end{array}$ & $\begin{array}{l}\text { EC } \\
\text { class }\end{array}$ & $\begin{array}{l}\text { SAR } \\
\text { class }\end{array}$ \\
\hline 1 & 391 & 7.20 & 2.16 & 3.84 & 49.6 & 69.7 & 64.3 & $\mathrm{C}_{3}$ & $\mathrm{~S}_{1}$ \\
\hline 2 & 288 & 7.12 & 3.84 & 4.55 & 57.5 & 80.3 & 56.9 & $\mathrm{C}_{3}$ & $\mathrm{~S}_{1}$ \\
\hline 3 & 407 & 9.48 & 5.24 & 5.11 & 56.1 & 75.7 & 52.0 & $\mathrm{C}_{3}$ & $\mathrm{~S}_{1}$ \\
\hline 4 & 439 & 5.32 & 0.60 & 3.63 & 46.6 & 65.1 & 53.6 & $\mathrm{C}_{3}$ & $S_{1}$ \\
\hline 5 & 686 & 6.88 & -3.76 & 1.43 & 22.1 & 39.4 & 77.3 & $\mathrm{C}_{3}$ & $\mathrm{~S}_{1}$ \\
\hline 6 & 184 & 1.76 & -0.08 & 1.09 & 30.4 & 65.4 & 50.0 & $\mathrm{C}_{2}$ & $\mathrm{~S}_{1}$ \\
\hline 7 & 399 & 6.76 & 2.60 & 4.24 & 52.1 & 71.2 & 52.0 & $\mathrm{C}_{3}$ & $\mathrm{~S}_{1}$ \\
\hline 8 & 120 & 0.32 & -0.40 & 1.23 & 37.7 & 73.7 & 30.0 & $\mathrm{C}_{1}$ & $S_{1}$ \\
\hline 9 & 276 & 5.08 & 2.28 & 4.71 & 59.3 & 79.6 & 50.7 & $\mathrm{C}_{3}$ & $\mathrm{~S}_{1}$ \\
\hline 10 & 263 & 3.72 & 0.12 & 1.66 & 35.5 & 62.9 & 68.2 & $\mathrm{C}_{3}$ & $S_{1}$ \\
\hline 11 & 527 & 4.28 & -2.36 & 1.51 & 25.5 & 45.2 & 62.9 & $\mathrm{C}_{3}$ & $S_{1}$ \\
\hline 12 & 483 & 4.28 & -0.68 & 0.83 & 16.2 & 41.9 & 51.2 & $\mathrm{C}_{3}$ & $S_{1}$ \\
\hline 13 & 631 & 5.96 & -3.64 & 1.31 & 21.0 & 39.5 & 75.9 & $\mathrm{C}_{3}$ & $\mathrm{~S}_{1}$ \\
\hline Min. & 120 & 0.32 & -3.76 & 0.83 & 16.2 & 39.4 & 30.0 & & \\
\hline Max. & 686 & 9.48 & 5.24 & 5.11 & 59.3 & 80.3 & 77.3 & & \\
\hline Mean & 392 & 5.24 & 0.46 & 2.70 & 39.2 & 62.3 & 57.3 & & \\
\hline
\end{tabular}

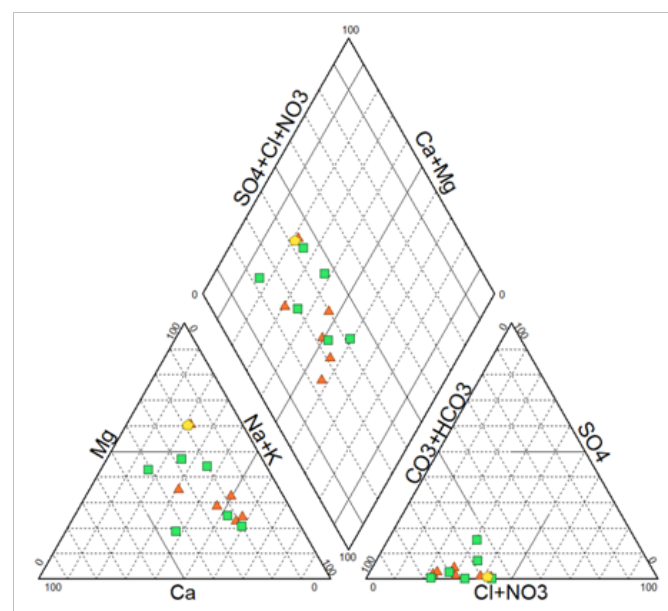

Figure 4. Piper diagram

\section{CONCLUSION}

The ground water quality of the farms of Horticultural College and Research Institute, Periyakulam indicated that the water samples were magnesium-dominated among cations followed by sodium, calcium and potassium. Magnesiumdominated water types were observed in a majority of the bore wells. Among the anions, bicarbonate was found to dominate, followed by chloride and sulphate. Total hardness indicated that most of the samples were coming under the very hard category. As most of the samples were under high salinity class $\left(\mathrm{C}_{3}\right)$, salinity persists in the ground waters. High salinity water can be used for irrigating soils with very good drainage, whereas very high salinity water is not suitable for irrigation for many of the soil groups. With regard to sodicity, most of the samples are coming under the low sodium category $\left(\mathrm{S}_{1}\right)$ and sodicity is not a major issue in the water samples. It was observed that these ground waters can be used for irrigation without permeability hazards in the soils. Overall, as per CSSRI, Karnal classification, majority of the samples are coming under good (76.9) followed by marginally alkaline (15.4\%) and alkaline (7.7\%). Hence, suitable management strategies may be followed to mitigate the adverse effects of the ground waters used for irrigation.

\section{AUTHOR CONTRIBUTIONS}

The research work was carried out with the funding from Tamil Nadu Agricultural University, Coimbatore. The idea conceptualization, conduct of experiments and writing of the original draft were done by K.M.Sellamuthu. Writing, reviewing and editing the original draft were carried out by P.Malathi and R.Kumaraperumal. 


\section{REFERENCES}

Ayers, R.S. and D.W.Westcot. 1994. Water quality for Agriculture. FAO Irrigation and drainage paper. Food and Agriculture Organization of the United Nations, Rome.p.197.

Doneen, L, D. 1966. Water quality requirement for agriculture. Proc. National Sym. Quality Standards for Natural Waters. University of Michigan, Ann. Report. p. 213-218.

Eaton, F.M. 1950. Significance of carbonates in irrigation waters. Soil Sci., 69: 123-133.

Environmental Protection Agency, 2001. Parameters of water quality Interpretation and Standards. Published by the Environmental Protection Agency, Ireland. P.58.

Gupta, I.C. 1983. Concept of residual sodium carbonate in irrigated waters in relation to sodic hazard in irrigated soils. Curr. Agric.,7: 97-113.

Gupta, S.K. and I.C.Gupta. 1987. Management of saline soils and waters. Oxford and IBH Publishing and Co, New Delhi. p. 339.

Gupta, R.K., N.T. Singh and M. Sethi. 1994. Ground water quality for irrigation in India. Technical Bulletin No. 90, CSSRI, Karnal pp.23.

Jeyaraj, M., A. Indhuleka and C. Arunpaul. 2019. Investigation of Water Quality Index of River Noyyal and Its Connected Ponds Coimbatore Tamil Nadu, India. Oriental J. of Chemistry., 35(3): 1125-1131.

Kesavan, K. G. and R. Parameswari, R. 2005. Evaluation of ground water quality in Kancheeppuram. Indian J. of Environ. Protection., 25(3) : 235-239.
Piper, A. M.1969. A graphic procedure in the geochemical interpretation of water analysis, USGS Groundwater Note no, 1953, p.12.

Raghunath, H.M. 1987. Groundwater. Wiley Eastern, New Delhi.

Richards, L.A. 1969. Diagnosis and improvement of Saline and Alkali Soils. United States Salinity Laboratory Staff. Agriculture Handbook No. 60. U.S. Government Printing Office, Washington, D.C.p.166.

Sellamuthu, K.M.,C.Mayilswami, A.Valliammaiand S. Chellamuthu. 2011. Effect of Textile and Dye Industrial Pollution on Irrigation Water Quality of Noyyal River Basin of Tamil Nadu. Madras Agric. J., 98 (4-6): 129-135.

Sellamuthu, K.M.,C.Mayilswami, A, Valliammai, and S. Chellamuthu. 2012. Assessment of Irrigation Water Quality in Parambikulam-Aliyar River Basin of Tamil Nadu. Madras Agric. J., 99 (4-6): 289-294.

Tiri, A., L. Belkhiri, and L. Mouni. 2018. Evaluation of surface water quality for drinking purposes using fuzzy inference system. Groundwater for Sustainable Development., 6:235-244.

Wilcox, L.V., G.Y. Blairand C.A. Bower.1954. Effect of bicarbonate on suitability of water for irrigation. Soil Sci., 77: 259-266.

Wilcox, L.V. 1955. Classification and Uses of Irrigation Water USDA Circular No. 969. Washington D.C., p. 19. 